\title{
How Do the Human Capital Characteristics of Entrepreneurial Team Influence Corporate Financial Performance?
}

\author{
Dan Long ${ }^{1}$, Yu-jing Tang ${ }^{1}$, Xiao-Zhi Fang ${ }^{2} \&$ Ke-Chun $\mathrm{Cai}^{3}$ \\ ${ }^{1}$ School of Management, Hefei University of Technology, Hefei, China \\ 2 Department of Economics and Management, Hefei University, Hefei, China \\ ${ }^{3}$ Anhui Meteorology Service, Hefei, China \\ Correspondence: Xiao-Zhi Fang, Department of Economics and Management, Hefei University, China. E-mail: \\ fangxz@hfuu.com.cn
}

Received: May 6, 2020

Accepted: June 26, 2020

Online Published: August 16, 2020

doi:10.5539/ijbm.v15n9p34

URL: https://doi.org/10.5539/ijbm.v15n9p34

\begin{abstract}
Researches on the direct impact of the characteristics of top management team on corporate financial performance have obtained many achievements for a long time. Little literatures studied the relationship between human capital characteristics of entrepreneurial team and corporate financial performance. Based on the Upper Echelons theory, this paper empirically tests the relationship among the characteristics of entrepreneurial team, debt financing scale and corporate financial performance. It collects 1221 valid data from the datasets of listed companies on ChiNext in 2014-2016. Using multiple regression analysis, this paper finds that human capital characteristics of entrepreneurial team have a significant impact on corporate financial performance as well as debt financing scale. Besides, the debt financing scale plays a partial mediating role. This paper enriches Upper Echelons theory by focusing on human capital characteristics of entrepreneurial team in new ventures. Previous studies usually pay their attention to the human capital characteristics of top management team in main board listed companies. Besides, by verifying the mediating effect of debt financing scale, this paper inspires to explore the indirect relationship between human capital characteristics of entrepreneurial team and corporate financial performance.
\end{abstract}

Keywords: human capital characteristics of entrepreneurial team, debt financing scale, financial performance

\section{Introduction}

As Romer and Lucas put forward the new growth theory, economic growth theory which is quiet for more than 20 years has been revived. The new economic growth theory believes that technological innovation drives economic growth. As is known to all, entrepreneurship is an important means for propelling technology innovation. At present, Chinese government stresses the importance of mass entrepreneurship and innovation, thus many entrepreneurs start businesses. However, due to the market uncertainty, many entrepreneurial projects are drowned and ultimately ended in failure. In 1979, Professor Timmons pointed out that entrepreneurial team can make up the shortcomings of individual entrepreneurship, entrepreneurial team is more likely to survive in uncertain environment. Therefore, it is important for start-ups to form and manage an outstanding entrepreneurial team.

In 1984, Hambrick and Mason proposed the Upper Echelons theory. The theory points out that there are some limitations of individual preference in decision-making process and team decision-making can effectively avoid this limitation. The theory suggests that research should focus on observable features of senior management teams. The core point of the Upper Echelons theory is that human capital characteristics of top management team can affect corporate governance, business decisions and performance. A long-run company needs the collective efforts, cooperation and group decision-making, which is conducive to the improvement of management efficiency and decision quality. The Upper Echelons theory focuses on the entire management team rather than CEO individuals. Taking the management team as a research unit not only retains the individual characteristics of the CEO, but also brings the characteristics of the whole management team into theoretical research model, which makes the theoretical model more powerful and can predict the effects of enterprise management more effectively. 
The Upper Echelons theory creates a new research field on human capital characteristics of team from organizational perspective. At the same time, debt financing decisions become more and more important for the financial performance in the process of establishing and developing corporate. After reading the existing researches, we find that there are some correlations among human capital characteristics, debt financing scale and corporate financial performance (Zahari, 2018; Samagaio \& Rodrigues, 2016; Custódio \& Metzger, 2014). What is the relationship among them? Is there a mediating factor such as debt financing scale existing between characteristics of entrepreneurial team and financial corporate performance?

There is a lot of literatures focuses on the impact of mature enterprise executive's human capital characteristics of on the scale of debt financing and corporate financial performance, but not enough attention to the entrepreneurial team of new venture (Zahari, 2018; Samagaio and Rodrigues, 2016). Besides, studies seldom explore the relationship between human capital characteristics and corporate financial performance from the mediating effect of debt financing perspective (Unger et al., 2011). Based on this, this paper investigates the relationship between human capital characteristics of entrepreneurial team and corporate financial performance mediating by debt financing scale. Through analyzing the datasets of ChiNext listed companies, this paper uncovers the "black box" between human capital characteristics of entrepreneurial team and corporate financial performance.

\section{Literature Review}

\subsection{Human Capital Characteristics of Entrepreneurial Team and Corporate Financial Performance}

Schultz (1960), an American economist, first expounds the theory of human capital systematically. The characteristics of human capital exist in individual, which is expressed as the sum of knowledge, skill and physical health. At this stage, measuring human capital characteristics of team has various ways, and they are all based on Upper Echelons theory proposed by Hambrick and Mason in 1984. The topics of these propositions include age, gender, other career experiences, education, financial position, group characteristics and the heterogeneity between team members (Hambrick \& Mason, 1984). These factors reflect manager's experience, sense of worth and other characteristics from different perspectives. They affect the creativity of top management team, the strategic decision and corporate performance (Alexiev et al., 2010, Amason et al., 2006).

There is a significant relationship between human capital characteristics of entrepreneurial team and corporate financial performance. Researching on the startups, Bendickson et al. (2017) find that human capital characteristics of entrepreneurial team affect the development and survival of new venture. Based on 70 independent samples, Unger et al. (2011) conclude that there is a significant but small relationship between human capital of entrepreneurial team and entrepreneurial success by meta-analyzing results from three decades of human capital research in entrepreneurship. Using teams in technology firms as samples, Hambrick et al. (2015) point that there is a positive relationship between team heterogeneity and firm performance, and structural independence is a positive moderator of these two variables.

\subsection{Debt Financing}

Scholars have conducted many researches on debt financing. On the one hand, human capital characteristics of entrepreneurial team have an impact on the size of debt issuing. Huang and Darren (2013) point out that male executives with financial background and better education, are more overconfident. Male executives issue debt more often than female executives. Bendickson et al. (2017) also find that better educated entrepreneurial team have more social resources than less educated entrepreneurial team, and education of entrepreneurial team can affect corporate financial decision-making. On the other hand, in the study of debt financing scale and corporate financial performance, Masulis (1983) finds that changes in debt level and leverage ratio positively affect the company's stock price and financial performance. Based on researches, there are some links among entrepreneurial team characteristics, debt financing scale and corporate financial performance. Our paper considers debt financing scale as a mediating variable based on the above discussion.

However, most of existing researches are concentrated on the top management teams of mature enterprises but not startups. Besides, scholars focus on studying the characteristics of individuals while the relationship of human capital characteristics of entrepreneurial team and corporate financial performance is not explored enough. Additionally, few scholars have studied the relationship among human capital characteristics of entrepreneurial team, debt financing scale and corporate financial performance systematically. Therefore, this paper selects debt financing scale as mediating variable to analyze the impact of human capital characteristics of entrepreneurial team on corporate financial performance. 


\section{Hypothesis}

The basic view of Upper Echelons theory is that human capital characteristics of team is regarded as an important factor in determining the company performance. And the different characteristics of team members leads team to analyze the external environment and make strategic decisions diversely. It finally affects corporate performance (Zahari, 2018). Therefore, this paper uses Upper Echelons theory to study entrepreneurial teams.

\subsection{Human Capital Characteristics of Entrepreneurial Team and Corporate Financial Performance}

When facing difficulties in the entrepreneurial process, entrepreneurial teams are more likely to respond appropriately compare with individual entrepreneur. They integrate individual advantages due to their diverse in knowledge and education background. As we know, the former literatures measure the characteristics of entrepreneurial team by setting indicators mainly including age, gender, education background, and experience (Marlow \& Macadam, 2012). After considering the availability of data, based on Upper Echelons theory, this paper selects three indicators to measure human capital characteristics of entrepreneurial team. The indicators are gender, education and financial experience.

Scholars find that gender difference leads to difference in management behavior (Fairlie \& Robb, 2009; Adams \& Ferreira, 2009). From the perspective of corporate performance, Fairlie and Robb (2009) point out that women-led companies are less successful. And their survival rate, profitability, number of employees and sales are all worse than men-led companies. Men are more often required to shape the image that is willing to bare social responsibility. They are good at dealing with risk. The risk-seeking trait of male members in entrepreneurial team may bring more opportunities to new venture and improve its financial performance (Fairlie $\&$ Robb, 2009). Therefore, this paper proposes the following hypothesis:

H1: The larger proportion of male members in entrepreneurial team makes corporate financial performance better.

With the increasingly fierce competition in domestic market, the knowledge reserve and application in company become more important for its development. Human capital obtained from education have been proven to be one of the strongest drivers of entrepreneurial performance (Millán \& Congregado, 2014; Unger et al. 2011). The cognitive ability, thinking orientation, professional level and other aspects of entrepreneurial team significantly related to education. Better educated entrepreneurial team can learn new knowledge faster, identify opportunities sooner, analyze problem more effectively, make better decision under complex as well as volatile market environments, and improve corporate financial performance (Subramaniam \& Youndt, 2005). Therefore, we propose the following hypothesis:

$\mathrm{H} 2$ : Better educated entrepreneurial team makes corporate financial performance better.

To a large extent, the professional background of entrepreneurial team, especially financial experience determines operational efficiency of startups. Entrepreneurial team members with financial experience can better manage new venture and improve corporate financial performance (Zahari, 2018). Entrepreneurial team with a background of accounting has the greatest positive impact on corporate financial performance. Because more financial experience entrepreneurs have, more attention be paid on financial quality control (Custódio \& Metzger, 2014). It is especially important for companies to increase market share and net profit. Therefore, these discussions lead to the following hypothesis:

H3: The larger proportion of members with financial experience in entrepreneurial team makes corporate financial performance better.

\subsection{Human Capital Characteristics of Entrepreneurial Team and Debt Financing Scale}

The difference in gender usually leads to differences in business strategies. Compared with female members, male members are more likely to seek risk and feel overconfident under environmental uncertainty (Huang \& Kisgen, 2013). After exploring the influence of entrepreneurs' gender on corporate financial and investment decisions, Huang and Kisgen (2013) find that male entrepreneurs with overconfidence are more willing to undertake acquisitions and issue debt. However, female entrepreneurs, who are relatively conservative, are more likely to exercise options early. Therefore, this paper proposes the following hypothesis:

H4: The larger proportion of male members in entrepreneurial team positively affects debt financing scale.

In general, education can reflect the cognitive ability and information processing ability (Millán et al., 2014). Well educated individuals in entrepreneurial team can deal with complex environmental changes by using professional skills. It also can reduce irrational decision-making (Oh et al., 2015). When members in entrepreneurial team is better educated, they have more social resources and be easier to obtain external 
financing resources (Millán et al., 2014). Besides, they show a more optimistic market expectation. They are more willing to accept high-level liabilities. Thus, we state the above as the following hypothesis:

H5: The education level of entrepreneurial team positively affects debt financing scale.

Compared with entrepreneurs without relevant career background, entrepreneurial team members with more relevant experience pay more attention to dynamic information in their field. It helps new enterprises to make better decisions (Oh et al., 2015). Entrepreneurs with financial experience have a better ability to use financial instruments for financing. And they show a lower degree of risk aversion (Oh et al., 2015). Custódio and Metzger (2014) find that managers with financial experience are prone to overconfidence and risk-seeking. They are more likely to raise external funds under tight credit conditions. Therefore, we propose the following hypothesis:

H6: The larger proportion of entrepreneurial team with financial experience positively affects debt financing scale.

\subsection{Human Capital Characteristics of Entrepreneurial Team, Debt Financing Scale and Corporate Financial Performance}

The human capital characteristics of entrepreneurial team influence financial decision-making behavior, which in turn affects the choice of financing methods. By effectively integrating internal and external resources, corporate executives can make reasonable strategic decisions (Hambrick, et al., 2015). On the one hand, the different human capital characteristics of entrepreneurial team lead to different perceptions and adaptability to the environment. Therefore, it directly affects the scale of debt financing (Malmendier, et al., 2011; Stephen, 1977). On the other hand, debt financing has many merits, such as agency costs reduction and information asymmetry evade, which has a positive impact on financial performance (Masulis, 1983). Alexiev et al. (2010) find that debt financing of listed companies can promote the market value of company. Thus, from the perspective of debt financing scale, this paper argues that there are some links between the characteristics of entrepreneurial team and corporate financial performance, and the links are implemented through debt financing. Therefore, we state the above as the following hypotheses:

H7: Debt financing scale plays a positive mediating role in the relationship between the proportion of male members in entrepreneurial team and corporate financial performance.

H8: Debt financing scale plays a positive mediating role in the relationship between the education level of entrepreneurial team and corporate financial performance.

H9: Debt financing scale plays a positive mediating role in the relationship between the proportion of members with financial experience in entrepreneurial team and corporate financial performance.

The theoretical model is shown in Figure 1.

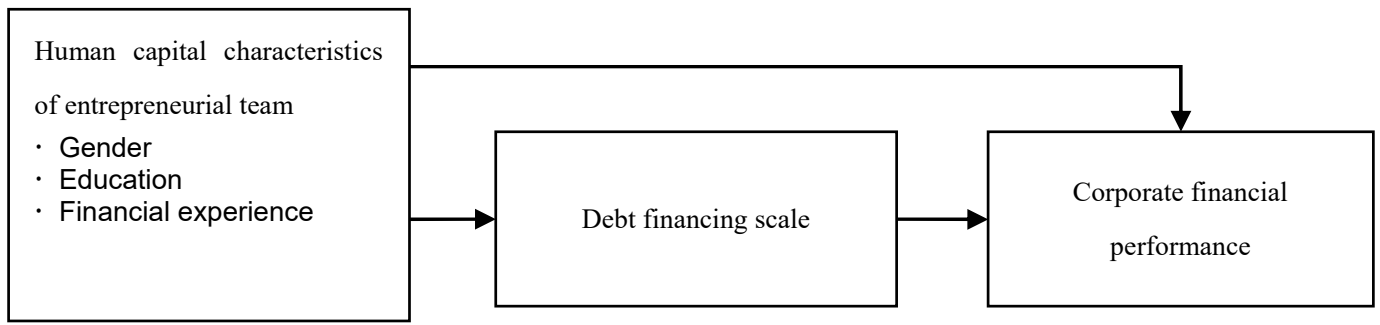

Figure 1. Theoretical model

\section{Measurement}

\subsection{Sample Selection and Data Sources}

We select the ChiNext listed companies from 2014 to 2016 as research samples. The data in this paper mainly comes from China stock market accounting research (CSMAR) databases and www.cninfo.com.cn. Some missing data are supplemented according to www.fechina.com.cn and finance.sina.com.cn. At the same time, the paper screens the sample according to the research designation: (1) We select the companies listed on ChiNext in 2016 after considering the stability and continuity of the sample; (2) after comparing and inquiring sample, we exclude some companies without relevant important data. Ultimately, we obtain 1221 valid data. In this paper, 
the original data is preprocessed by SPSS 19.0.

\subsection{Variable Measurement}

Dependent variable This paper takes the corporate financial performance as dependent variable. Scholars usually use Tobin Q value to measure enterprise performance. Chinese capital market is not very effective. There is a lot of non-trading stocks in equity of enterprise. Thus, Tobin $\mathrm{Q}$ value represents enterprise performance has some limitation. Besides that, Return on Equity (ROE) is an internationally accepted indicator of company performance. It measures the proportional relationship between company's net income and equity. It can reflect corporate financial performance from profitability, operational capability. In addition, ROE is not only a comprehensive financial indicator, but also a significant ratio in disclosing financial information. The researching object of this study is corporate financial performance. Therefore, ROE is selected to measure financial performance of listed companies on the ChiNext. We use "net income/average shareholder' equity" to measure ROE.

Independent variable Human capital characteristics of entrepreneurial team is independent variable. We select three factors to measure human capital characteristics of entrepreneurial team, including gender, education, and financial experience. For factor of gender, " 1 " is assigned to male member in entrepreneurial team and " 0 " is assigned to female entrepreneur. For factor of entrepreneurial team' education, " 1 " is denoted as senior high or below, " 2 " is denoted as junior college, " 3 " is denoted as bachelor, "4" is denoted as master and " 5 " is denoted as $\mathrm{PhD}$ or above. We divide entrepreneurial team members by adding up the former values. For factor of financial experience, if members in entrepreneurial team have financial experience, he/she is assigned to "1", and vice versa, assigned to " 0 ". We divide the entrepreneurial team members by adding up the former values.

Mediating variable This paper selects the debt financing scale as mediating variable. The indicator of asset to liability ratio is used to measures debt financing scale. Asset to liability ratio is measured by total liabilities/total assets.

Control variables We choose company size, growth, fixed asset ratio and shareholder concentration as control variables. Besides, considering the impact of sample data on industry and time spans, this paper generates dummy variables by year and industry. According to the industry classification standards of the China Securities Regulatory Commission in 2012, the industries in sample are classified into 13 categories.

The measurement of the variables is shown in Table 1.

Table 1. The measurement of main variables

\begin{tabular}{|c|c|c|c|}
\hline Variable & Indicator & Abbreviation & Measurement \\
\hline $\begin{array}{ll}\text { corporate } & \text { financial } \\
\text { performance } & \end{array}$ & return on equity & ROE & net income/average shareholders' equity \\
\hline \multirow{3}{*}{$\begin{array}{l}\text { Human cap } \\
\text { characteristics } \\
\text { entrepreneurial team }\end{array}$} & gender & Gender & $\begin{array}{l}\text { " } 1 \text { " is assigned to the male member in entrepreneurial team and " } 0 \text { " is } \\
\text { assigned to the female, then divide the entrepreneurial team members by } \\
\text { adding up the former values }\end{array}$ \\
\hline & education & Edu & $\begin{array}{l}\text { " } 1 \text { " is denoted as senior high or below, " } 2 \text { " is denoted as junior college, " } 3 \text { " } \\
\text { is denoted as bachelor," } 4 \text { " is denoted as master and " } 5 \text { " is denoted as } \mathrm{PhD} \\
\text { or above, then divide the entrepreneurial team members by adding up the } \\
\text { former values }\end{array}$ \\
\hline & $\begin{array}{l}\text { financial } \\
\text { experience }\end{array}$ & $\mathrm{Fe}$ & $\begin{array}{l}\text { if members in entrepreneurial team have financial experience, he/she is } \\
\text { assigned to " } 1 \text { ", and vice versa, assigned to " } 0 \text { ", then divide the } \\
\text { entrepreneurial team members by adding up the former values }\end{array}$ \\
\hline \multirow[t]{4}{*}{ debt financing scale } & $\begin{array}{l}\text { asset to liability } \\
\text { ratio }\end{array}$ & DAR & total liabilities/total assets \\
\hline & company size & Size & natural logarithm value of total assets at the end of the year \\
\hline & growth & Growth & $\begin{array}{l}\text { (sales of current year-sales at the beginning of year)/sales at the beginning } \\
\text { of year }\end{array}$ \\
\hline & fixed asset ratio & Far & net fixed assets/total assets \\
\hline \multirow[t]{3}{*}{ control variables } & $\begin{array}{l}\text { ownership } \\
\text { concentration }\end{array}$ & $\mathrm{S}_{10}$ & the sum of shareholding proportions of top 10 shareholders \\
\hline & industry & Industry & $\begin{array}{l}\text { generate dummy variables according to industry. For example, if a company } \\
\text { belongs to a certain industry, it is assigned to " } 1 \text { ", and vice versa, assigned } \\
\text { to " } 0 \text { ". }\end{array}$ \\
\hline & year & Year & $\begin{array}{l}\text { generate dummy variables according to year. For example, if a data belongs } \\
\text { to a certain year, it is assigned to " } 1 \text { ", and vice versa, assigned to "0". }\end{array}$ \\
\hline
\end{tabular}




\subsection{Modeling}

In order to test the relationship between human capital characteristics of entrepreneurial team and corporate financial performance, this paper establishes the model 1 and the model 2:

$$
\begin{aligned}
& \quad R O E=\beta_{0}+\beta_{1} \text { Size }+\beta_{2} \text { Growth }+\beta_{3} \text { Far }+\beta_{4} S_{10}+\beta_{5} \text { Industry }+\beta_{6} \text { Year }+\varepsilon \\
& R O E=\beta_{0}+\beta_{1} \text { Gender }+\beta_{2} E d u+\beta_{3} F \mathrm{e}+\beta_{4} \text { Size }+\beta_{5} \text { Growth }+\beta_{6} \text { Far }+\beta_{7} S_{10}+\beta_{8} \text { Industry } \\
& +\beta_{9} \text { Year }+\varepsilon
\end{aligned}
$$

Among them, the dependent variable is ROE, the independent variables are Gender, Edu and Fe, and the control variables are company size, growth, fixed asset ratio (Far) and shareholder concentration $\left(\mathrm{S}_{10}\right)$. Besides, we also verify the impact of industry and year.

For testing the relationship between human capital characteristics of entrepreneurial team and debt financing scale, we establish the model 3 and model 4:

$$
\begin{gathered}
D A R=\beta_{0}+\beta_{1} \text { Size }+\beta_{2} \text { Growth }+\beta_{3} \text { Far }+\beta_{4} \text { Industry }+\beta_{5} \text { Year }+\varepsilon \\
D A R=\beta_{0}+\beta_{1} \text { Gender }+\beta_{2} E d u+\beta_{3} F \mathrm{e}+\beta_{4} \text { Size }+\beta_{5} \text { Growth }+\beta_{6} \text { Far }+\beta_{7} \text { Industry }+\beta_{8} \text { Year }+\varepsilon
\end{gathered}
$$

Among them, DAR is dependent variable and represents debt financing scale. Gender, Edu, and Fe are independent variables which represent the gender, education, and financial experience of the entrepreneurial team members respectively. The company size, growth, and fixed asset ratio (Far) are control variables. At the same time, we verify the impact of the industry and year.

In order to test the mediating role of debt financing scale between human capital characteristics of entrepreneurial team and corporate financial performance, this paper sets the model 5 :

$$
\begin{aligned}
& R O E=\beta_{0}+\beta_{1} \text { Gender }+\beta_{2} E d u+\beta_{3} F \mathrm{e}+\beta_{4} D A R+\beta_{5} \text { Size }+\beta_{6} \text { Growth }+\beta_{7} \text { Far }+\beta_{8} S_{10} \\
& +\beta_{9} \text { Industry }+\beta_{10} \text { Year }+\varepsilon
\end{aligned}
$$

Among them, ROE is a dependent variable, representing the return on equity of the enterprise. Gender, Edu, $\mathrm{Fe}$ are independent variables, which represent gender, education and financial experience of entrepreneurial team members. DAR is the mediate variable, which means the asset to liability ratio of corporate. We set the company size, growth, fixed asset ratio (Far) and shareholder concentration $\left(\mathrm{S}_{10}\right)$ as control variables while verifying the impact of the industry and year.

\subsection{Methodology}

This paper uses SPSS19.0 to analyze the selected datasets of listed companies on ChiNext in 2014-2016. The methodologies are following: (1) Descriptive statistics. It helps us to judge the overall situation of the sample and its rationality. (2) Correlation analysis. In this paper, Pearson coefficient correlation analysis method is used to judge the relationship among variables preliminarily, in order to test whether there is multiple collinearity among variables. (3) Regression analysis. In this paper, we verify the proposed hypotheses by regression analysis.

\section{Results}

\subsection{Descriptive Statistics}

After screening the sample data, 1221 valid samples are obtained. The samples descriptive statistics of all variables are shown in Table 2.

The mean of corporate financial performance is 0.076 , the standard deviation is 0.097 , and the maximum and minimum values are 0.577 and -1.422 , indicating that there is a great difference in financial performance between different companies. The average asset to liability ratio of corporate is 0.304 , expressing that liability of sample enterprises is not high and companies are more likely to use equity financing to raise money. The average gender of entrepreneurial team is 0.797 , which shows that the proportion of male in entrepreneurial team of ChiNext listed companies is relatively large. The average education level of entrepreneurial team is 3.382 , revealing that entrepreneurial team members are mainly obtain master's degree. And there is approximately $23.1 \%$ of the members of entrepreneurial team with financial experience, because the average members' financial experience is 0.231 . 
Table 2. The descriptive statistics of main variables

\begin{tabular}{llllll}
\hline Variable & Sample & Mean & Standard deviation & Max & Min \\
\hline ROE & 1221 & 0.076 & 0.097 & 0.577 & -1.422 \\
Gender & 1221 & 0.797 & 0.111 & 1 & 0 \\
Edu & 1221 & 3.382 & 0.385 & 5 & 1.882 \\
Fe & 1221 & 0.231 & 0.085 & 1 & 0 \\
DAR & 1221 & 0.304 & 0.166 & 0.886 & 0.014 \\
Size & 1221 & 21.343 & 0.752 & 24.196 & 19.29 \\
Growth & 1221 & 0.571 & 1.397 & 22.558 & -2.215 \\
Far & 1221 & 0.167 & 0.119 & 0.557 & 0.001 \\
$\mathrm{~S}_{10}$ & 1221 & 58.719 & 11.909 & 91.703 & 15.953 \\
\hline
\end{tabular}

\subsection{Correlation Analysis}

In order to test the correlation and multi-collinearity among variables, we use Pearson coefficient correlation analysis. The results are shown in Table 3. From the results of the two-sided test, gender, education and financial experience of entrepreneurial team are positively correlated with debt financing scale $(\gamma=0.097, \mathrm{P}<0.01 ; \gamma=0.138$, $\mathrm{P}<0.01 ; \gamma=0.224, \mathrm{P}<0.01)$. And these three characteristics of entrepreneurial team are positively related to corporate financial performance $(\gamma=0.048, \mathrm{P}<0.1 ; \gamma=0.168, \mathrm{P}<0.01 ; \gamma=0.138, \mathrm{P}<0.01)$. Additionally, debt financing scale is positively related to corporate financial performance $(\gamma=0.127, \mathrm{P}<0.01)$. The results show that there is a correlation between human capital characteristics of entrepreneurial team, debt financing scale and corporate financial performance. Besides, the absolute values of the correlation coefficients among variables are relatively small, so there is no multi-collinearity among them. Thus, regression analysis can be performed.

Table 3. Correlation analysis of main variables

\begin{tabular}{llllllllll}
\hline & ROE & Gender & Edu & Fe & DAR & Size & Growth & Far & S $_{10}$ \\
\hline ROE & 1 & - & - & - & - & - & - & - & - \\
Gender & $0.048^{*}$ & 1 & - & - & - & - & - & - & - \\
Edu & $0.168^{* * *}$ & -0.04 & 1 & - & - & - & - & - & - \\
Fe & $0.138^{* * *}$ & -0.039 & $0.089^{* * *}$ & 1 & - & - & - & - & - \\
DAR & $0.127^{* * *}$ & $0.097^{* * *}$ & $0.138^{* * *}$ & $0.224^{* * *}$ & 1 & - & - & - & - \\
Size & $0.170^{* * *}$ & 0.023 & $0.217^{* * *}$ & 0.037 & $0.420^{* * *}$ & 1 & - & - & - \\
Growth & -0.042 & $-0.001^{*}$ & $0.070^{* *}$ & -0.016 & 0.017 & 0.04 & 1 & - & - \\
Far & $-0.122^{* * *}$ & $0.056^{*}$ & $-0.246^{* * *}$ & 0.021 & 0.024 & $-0.138^{* * *}$ & $-0.146^{* * *}$ & 1 & - \\
$\mathrm{S}_{10}$ & $0.120^{* * *}$ & $-0.067^{* *}$ & $-0.132^{* * *}$ & -0.022 & $-0.101^{* * *}$ & $-0.174^{* * *}$ & -0.047 & $0.053^{*}$ & 1 \\
\hline
\end{tabular}

Note. $* * *$ and $* * *$ are represent the two tailed significance level of $10 \%, 5 \%, 1 \%$ respectively.

\subsection{Regression Analysis}

\subsubsection{Human Capital Characteristics of Entrepreneurial Team and Corporate Financial Performance}

The regression results of human capital characteristics of entrepreneurial team and corporate financial performance are shown in Table 4. The F values of model 1 and model 2 are both significant at the level of $1 \%$. Model 1 is a regression model with only control variables added. In model 1, the company size and ownership concentration positively affect the corporate financial performance $(\beta=0.174, \mathrm{P}<0.01 ; \beta=0.135, \mathrm{P}<0.01)$. Besides, the growth and fixed asset ratio negatively affect the corporate financial performance $(\beta=-0.050, P<0.1 ; \beta=-0.102$, $\mathrm{P}<0.01$ ). In model 2 , there is a significant positive relationship between human capital characteristics of entrepreneurial team and corporate financial performance. This shows that the higher the proportion of male members of the entrepreneurial team in the listed companies on the ChiNext, the more overconfident and risk preference the entrepreneurship team has, thus the better the corporate financial performance $(\beta=0.073, \mathrm{P}<0.01)$. $\mathrm{H} 1$ is verified. $\mathrm{H} 2$ is also validated $(\beta=0.122, \mathrm{P}<0.01)$. The better educated entrepreneurial team is more capable to acquire knowledge and solve problems, so it has better corporate financial performance. Besides, the higher proportion of team members with financial experience, the deeper their understanding of company's financial situation and capital market. It promotes the financial performance of enterprise $(\beta=0.144, \mathrm{P}<0.01)$, thus $\mathrm{H} 3$ is validated. 
Table 4. The regression result

\begin{tabular}{lll}
\hline Variable & Model 1 & Model 2 \\
\hline Constant & $-0.455^{* * *}$ & $-0.570^{* * *}$ \\
& $(-5.279)$ & $(-6.510)$ \\
Size & $0.174^{* * *}$ & $0.144^{* * *}$ \\
& -5.746 & -4.78 \\
Growth & $-0.050^{*}$ & $-0.052^{*}$ \\
& $(-1.787)$ & $(-1.897)$ \\
Far & $-0.102^{* * *}$ & $-0.082^{* * *}$ \\
& $(-3.305)$ & $(-2.694)$ \\
S10 & $0.135^{* * *}$ & $0.152^{* * *}$ \\
& -4.783 & -5.473 \\
Gender & - & $0.073^{* * *}$ \\
& & -2.716 \\
Edu & - & $0.122^{* * *}$ \\
& & -4.242 \\
Fe & - & $0.144^{* * *}$ \\
Industry & controlled & -5.3 \\
Year & controlled & controlled \\
$\mathrm{R}^{2}$ & 0.121 & controlled \\
Adjusted R & 0.108 & 0.161 \\
F-value & $9.180^{* * *}$ & 0.146 \\
Observed value & 1221 & $10.927^{* * *}$ \\
\hline
\end{tabular}

Note. *, ** and *** are represent the significance level of $10 \% 、 5 \% 、 1 \%$ respectively; The $\mathrm{T}$ value is in parentheses.

\subsubsection{The Human Capital Characteristics of Entrepreneurial Team and Debt Financing Scale}

The regression results of human capital characteristics of entrepreneurial team and debt financing scale are shown in Table 5. The F values of model 3 and model 4 are both significant at the $1 \%$ level. In model 3, the regression results show that the control variables of company size and fixed asset ratio positively affect company's asset to liability ratio $(\beta=0.433, \mathrm{P}<0.01 ; \beta=0.088, \mathrm{P}<0.01)$. In model 4 , the proportion of male members in entrepreneurial team $(\beta=0.097, \mathrm{P}<0.01)$, the education $(\beta=0.046, \mathrm{P}<0.1)$ and the proportion of members with financial experience $(\beta=0.218, \mathrm{P}<0.05)$ all positively affect the size of debt financing. Thus $\mathrm{H} 4$, $\mathrm{H} 5$ and $\mathrm{H} 6$ are verified.

Table 5. The regression result

\begin{tabular}{lll}
\hline Variable & Model 3 & Model 4 \\
\hline \multirow{2}{*}{ Constant } & $-1.752^{* * *}$ & $-1.967^{* * *}$ \\
& $(-13.492)$ & $(-15.001)$ \\
Size & $0.433^{* * *}$ & $0.413^{* * *}$ \\
& -15.607 & -15.137 \\
Growth & 0.027 & 0.026 \\
& -1.035 & -1.032 \\
Far & $0.088^{* * *}$ & $0.095^{* * *}$ \\
& -3.09 & -3.402 \\
Gender & - & $0.097^{* * *}$ \\
& & -3.923 \\
Edu & - & $0.046^{*}$ \\
& & -1.758 \\
Fe & - & $0.218^{* *}$ \\
Industry & controlled & -8.76 \\
Year & controlled & controlled \\
$\mathrm{R}^{2}$ & 0.242 & 0.298 \\
Adjusted $\mathrm{R}^{2}$ & 0.231 & 0.287 \\
F-value & $22.556^{* * *}$ & $25.497^{* * *}$ \\
Observed value & 1221 & 1221 \\
\hline
\end{tabular}

Note. $* * *$ and $* * *$ are represent the significance level of $10 \%, 5 \%, 1 \%$ respectively; The $\mathrm{T}$ value is in parentheses. 
5.3.3 The Human Capital Characteristics of Entrepreneurial Team, Debt Financing Scale and Corporate Financial Performance

The regression results of human capital characteristics of entrepreneurial team, debt financing scale and corporate financial performance are shown in Table 6. The F value of model 5 is significant at the $1 \%$ level, which assumes that the regression analysis is significant. Firstly, from the results in Table 4, the human capital characteristics of entrepreneurial team have a significant influence on corporate financial performance, satisfying the first step of mediation effect test. Secondly, according to the outcome in Table 5, we know the human capital characteristics of entrepreneurial team have a significant effect on the scale of debt financing, which fulfills the second step of mediation effect test. Finally, the regression results in Table 6 show that after incorporating the human capital characteristics of entrepreneurial team and corporate financial performance into the model. The regression results are still significant and the overall fitness of model 5 is improved compared with model 2(Adjusted $\mathrm{R}^{2}=0.148, \mathrm{~F}=10.637, \mathrm{P}<0.01$ ). Thus, we can conclude that the scale of debt financing as a mediating variable plays a partial role in the process of the human capital characteristics of entrepreneurial team affecting the corporate financial performance.

Table 6. The regression result

\begin{tabular}{ll}
\hline Variable & Model 5 \\
\hline Constant & $-0.506^{* * *}$ \\
& $(-5.413)$ \\
Size & $0.118^{* * *}$ \\
& -3.604 \\
Growth & $-0.053^{*}$ \\
& $(-1.957)$ \\
Far & $-0.088^{* * *}$ \\
& $(-2.879)$ \\
$\mathrm{S}_{10}$ & $0.153^{* * *}$ \\
& -5.521 \\
Gender & $0.054^{*}$ \\
& -1.951 \\
Edu & $0.119^{* * *}$ \\
& -4.144 \\
Fe & $0.131^{* * *}$ \\
& -4.656 \\
DAR & $0.063^{* *}$ \\
Industry & -1.998 \\
Year & Controlled \\
$\mathrm{R}^{2}$ & Controlled \\
Adjusted $\mathrm{R}^{2}$ & 0.163 \\
F-value & 0.148 \\
\hline Observed value & $10.637^{* * *}$ \\
& 1221 \\
\hline represent the significance level of $10 \%$ respectively; The T value is in parentheses. \\
\end{tabular}

To further test the mediating effect of debt financing scale, we exam whether the coefficient $c^{\prime}$ of each human capital characteristics of entrepreneurial team is significant for the reduction of the regression coefficient $\mathrm{c}$ before debt financing is added. Among them, the calculation method of the statistic $\mathrm{T}$ is:

$$
\mathrm{t}_{N-2}=\frac{\left|c-c^{\prime}\right|}{\sqrt{S_{c}^{2}+S_{c^{\prime}}^{2}-2 S_{c} S_{c} \cdot \sqrt{1-\rho_{x m}^{2}}}}
$$

Where, Sc and Sc' are the standard deviation of $\mathrm{c}$ and $\mathrm{c}^{\prime}$ respectively. In the test tables, SE refers to the standard error, and $\rho_{\mathrm{xm}}$ is the correlation coefficient between human capital characteristics of entrepreneurial team and debt financing scale. The $\mathrm{T}$ test results are shown in Table 7, Table 8 and Table 9. 
Table 7. The mediating effect test of debt financing scale 1

\begin{tabular}{llllll}
\hline Dependent variable & step & standardized regression equation & regression coefficient test & mediating effect (\%) & T-value \\
\hline \multirow{3}{*}{ ROE } & 1 & ROE $=0.063$ gender & $\mathrm{SE}=0.024 ; \mathrm{t}=2.29$ & & \\
& 2 & $\mathrm{DAR}=0.087$ gender & $\mathrm{SE}=0.038 ; \mathrm{t}=3.36$ & $15.05 \%$ & 4.31 \\
& 3 & ROE=0.054gender + & $\mathrm{SE}=0.024 ; \mathrm{t}=1.95$ & & \\
& & & & & \\
\end{tabular}

Table 8 . The mediating effect test of debt financing scale 2

\begin{tabular}{llllll}
\hline Dependent variable & step & standardized regression equation & regression coefficient test & mediating effect (\%) & T-value \\
\hline \multirow{2}{*}{ ROE } & 1 & ROE $=0.135 \mathrm{edu}$ & $\mathrm{SE}=0.007 ; \mathrm{t}=4.66$ & & \\
& 2 & DAR $=0.065 \mathrm{edu}$ & $\mathrm{SE}=0.012 ; \mathrm{t}=2.39$ & $5.10 \%$ & 15.38 \\
& \multirow{2}{*}{3} & ROE $=0.128 \mathrm{edu}+$ & $\mathrm{SE}=0.007 ; \mathrm{t}=4.43$ & & \\
& & & & & \\
\hline
\end{tabular}

Table 9. The mediating effect test of debt financing scale 3

\begin{tabular}{llllll}
\hline Dependent variable & step & standardized regression equation & regression coefficient test & mediating effect(\%) & T-value \\
\hline \multirow{2}{*}{ ROE } & 1 & ROE $=0.154 \mathrm{Fe}$ & $\mathrm{SE}=0.031 ; \mathrm{t}=5.64$ & & \\
& 2 & $\begin{array}{l}\mathrm{DAR}=0.219 \mathrm{Fe} \\
\mathrm{ROE}=0.137 \mathrm{Fe}+\end{array}$ & $\mathrm{SE}=0.049 ; \mathrm{t}=8.78$ & $10.95 \%$ & 2.42 \\
& 3 & $\mathrm{SE}=0.032 ; \mathrm{t}=4.87$ & & \\
\hline
\end{tabular}

As we know, Sample $\mathrm{N}=1221, \mathrm{t}_{0.01}(1219)=2.5758, \mathrm{t}_{0.05}(1219)=1.96, \mathrm{t}_{0.1}(1219)=1.6449$. According to the data in Table 7, Table 8, and Table 9, the variables' t-test values of the human capital characteristics of entrepreneurial team are all greater than the critical value at 5\% level. Therefore, the mediating effect of debt financing on the relationship of human capital characteristics of entrepreneurial team and corporate financial performance is significant which the ratios of mediating effects are $15.05 \%, 5.10 \%$ and $10.95 \%$ respectively. Finally, we conclude that $\mathrm{H} 7, \mathrm{H} 8$, and $\mathrm{H} 9$ are all verified.

\section{Discussion}

After Timmons (1979) firstly pointed out that entrepreneurial team can make up the shortcomings of individual entrepreneurship, a lot of scholars show an enduring interest in the topic of entrepreneurial team, especially the human capital characteristics of entrepreneurial team (Zahari, 2018; Samagaio \& Rodrigues, 2016; Oh et.al., 2015; Huang \& Kisgen, 2013; Unger et. al., 2011; Amason et.al., 2006). In this study, we explore how the human capital characteristics of entrepreneurial team influence corporate financial performance. By analyzing the datasets of ChiNext listed companies, this paper empirically tests the relationship among human capital characteristics of entrepreneurial team, financing debt scale and corporate financial performance.

Firstly, human capital characteristics of entrepreneurial team have a significant impact on the corporate financial performance. When entrepreneurial team has more male members, better educated, and more members has financial experience, the entrepreneurial team performs more risky preference. It brings more opportunities to company and thus improves corporate financial performance. This result is as same as the most previous researches' result (Zahari, 2018; Samagaio \& Rodrigues, 2016; Huang \& Kisgen, 2013; Unger et. al., 2011; Amason et.al., 2006;). However, research by Oh et.al. explored in 2015 indicate that the characteristics of management team are related to organization-level managerial job satisfaction and labor productivity, however they are not related to financial performance. The contrary result may attribute to researching situation of these two studies. We focus on human capital characteristics of entrepreneurial team in new ventures, such as gender, education and financial experience. However, the study made by Oh et. al. stress on emotional stability, extraversion, and conscientiousness of team members in established business.

Secondly, the human capital characteristics of entrepreneurial team have a positive effect on the company debt scale. A larger proportion of male members in entrepreneurial team can positively affects debt financing scale. Male members are more over-confident and prefer debt issues. The education level of entrepreneurial team positively affects the scale of debt financing. Compare with less educated entrepreneur, well-educated entrepreneurs have more social resources and easier access to debt financing channels. A larger proportion of members with financial experience positively affects debt financing scale. Members with financial work experience have stronger financial knowledge and more ways of debt financing. For other studies such as the 
study of Huang and Kisgen published in 2013, they also find that men exhibit relative overconfidence in significant corporate decision making such as debt issues and acquisitions compared with women.

Finally, the scale of debt financing plays a partial mediating role in the process of human capital characteristics of entrepreneurial team influencing the corporate financial performance. The human capital characteristics of entrepreneurial team influence the choice of financing methods. Moreover, debt financing can help to reduce agency costs and avoid information asymmetry, which has a positive impact on financial performance. After Unger et. al (2011) suggest that future research should pursue moderator approaches to study the effects of human capital on success, some researches focus their study on the moderating effect of the human capital characteristics of entrepreneurial team and corporate success. For example, Amason et. al. (2006) argue that venture performance should reflect, at least partially, the fit between the characteristics of the TMT and the level of venture novelty. Our study creatively explores the mediating variable of debt financing scale. The result indicate that the human capital characteristics of entrepreneurial team influence financial decision-making behavior and the choice of financing methods. The debt financing scale has a positive impact on financial performance.

\section{Conclusion and Implications}

Based on the Upper Echelons theory, this paper empirically tests how human capital characteristics of entrepreneurial team influence corporate financial performance from the perspective of debt financing scale. By analyzing the datasets of ChiNext listed companies, this paper finds that the human capital characteristics of entrepreneurial team have a positive effect on corporate financial performance and debt financing scale. And the debt financing scale is a partial mediator between human capital characteristics of entrepreneurial team and corporate financial performance.

The theoretical implications of this research are following. On the one hand, this paper is helpful to enrich the intension and extension of Upper Echelons theory. Previous studies focused on the impact of human capital characteristics of top management team on corporate financial performance, but not enough attention has been paid to entrepreneurial team. This paper pays more attention to new ventures. On the other hand, this paper inspires to explore the indirect relationship between human capital characteristics of entrepreneurial team and corporate financial performance. Most researches focus on direct influence of human capital characteristics of entrepreneurial team on corporate financial performance. This paper verifies the mediating effect of debt financing scale, it can enlighten researchers to explores the indirect relationship from other perspectives.

This research has two important enlightenments on entrepreneurial practice. First, entrepreneurial team members should improve their self-awareness and enrich their knowledge and experience. In decision-making process, female members should strive to overcome over-caution and risk aversion. And entrepreneurial members should never stop learning and educating. Moreover, entrepreneurial team should also actively engage in financial related work and improve the corporate financial performance from a professional perspective. Second, for the entrepreneurial team, it is necessary not only to optimize team composition, but also to improve the financing decision, such as debt issues.

This paper also has some limitations. Firstly, we only choose the data of ChiNext listed companies for two years. This small sample size may have some limitations on the accuracy of results. Results may vary in large samples. Secondly, based on the existing research results, we adopt return on assets to measure corporate financial performance. The index system is relatively single and fails to fully reflect the financial performance level of listed companies on ChiNext. Thirdly, we only consider three factors in human capital characteristics of entrepreneurial team. We should consider other factors such as psychological characteristics, social background and team heterogeneity, etc. Finally, the human capital characteristics of entrepreneurial team does not affect corporate financial performance entirely through debt financing. The conductive effect of debt financing scale on the human capital characteristics of entrepreneurial team is only partially transmitted, and the distribution decision may also play a conduction effect, which is worth studying.

\section{Funding}

This research is supported by the National Natural Science Foundation of China (No. 71772055), Humanities and Social Sciences of Ministry of Education Planning Fund of China (No. 17YJA630067), Anhui Philosophical and Social Science Program (No. AHSKY2019D030), Fundamental Research Funds for the Central Universities (No. JZ2019HGTB0094), and Excellent Young Talents in Colleges and Universities in Anhui Province Department of Education Project (key project) (No. GXYQZD2017076). 


\section{Acknowledgements}

The authors would like to thank the reviewers for their valuable comments. Gratitude is also extended to all authors of literatures cited in this article.

\section{References}

Adams, R., \& Ferreira, D. (2009). Women in the boardroom and their impact on governance and performance. Journal of Financial Economics, 94(2), 291-309. https://doi.org/10.1016/j.jfineco.2008.10.007

Alexiev, A. S., Jansen, J. J. P., Van Den Bosch, \& Frans, A. J., \& Volberda, H. W. (2010). Top management team advice seeking and exploratory innovation: The moderating role of TMT heterogeneity. Journal of Management Studies, 47(7), 1343-1364. https://doi.org/10.1111/j.1467-6486.2010.00919.x

Amason, A. C., Shrader, R. C., \& Tompsom, G. H. (2006). Newness and novelty: Relating top management team composition to new venture performance. Journal of Business Venturing, 21(1), 125-148. https://doi.org/10.1016/j.jbusvent.2005.04.008

Atkinson, S., Baird, S., \& Frye, M. (2003). Do female mutual fund managers manage differently? Journal of Financial Research, 26, 1-18. https://doi.org/ 10.1111/1475-6803.00041

Bantel, K. A., \& Jackson, S. E. (1989). Top management and innovations in banking: Does the composition of the top team Make a Difference? Strategic Management Journal, 10(5), 107-124. https://doi.org/10.1002/smj.4250100709

Bendickson, J., Muldoon, J., Ligouri, E., \& Midgett, C. (2017). High performance work systems: A necessity for startups. Journal of Small Business Strategy, 27(2), 1-12.

Custódio, C., \& Metzger, D. (2014). Financial expert CEOs: CEO's work experience and firm's financial policies. Journal of Financial Economics, 114(1), 125-154. https://doi.org/10.1016/j.jfineco.2014.06.002

Doms, M., Lewis, E., \& Robb, A. (2010). Local labor force education, new business characteristics, and firm performance. Urban Economics, 67(1), 61-77.

Fairlie, R. W., \& Robb, A. M. (2009). Gender differences in business performance: Evidence from the characteristics of business owners survey. Small Business Economics, 33(4), 375-395. https://doi.org/10.1007/s11187-009-9207-5

Hambrick, D. C., \& Mason, P. A. (1984). Upper echelons: The organization as a reflection of its top managers. Social Science Electronic Publishing, 9(2), 193-206. https://doi.org/10.5465/amr.1984.4277628

Hambrick, D. C., Humphrey, S. E., \& Gupta, A. (2015). Structural interdependence within top management teams: A key moderator of upper echelons predictions. Strategic Management Journal, 36(3), 449-461. https://doi.org/10.1002/smj.2230

Huang, J., \& Kisgen, D. J. (2013). Gender and corporate finance: Are male executives overconfident relative to female executives? Social Science Electronic Publishing, 108(3), 822-839. https://doi.org/10.1016/j.jfineco.2012.12.005

Malmendier, U., Tate, G., \& Yan, J. (2011). Overconfidence and early-life experience: The effect of managerial traits on corporate finance policies. The Journal Finance, 66(5), 1687-1733. https://doi.org/10.2307/41305173

Marlow, S., \& Macadam, M. (2012). Analyzing the influence of gender upon high-technology venturing within the context of business incubation. Entrepreneurship Theory and Practice, 36(4), 655-676. https://doi.org/10.1111/j.1540-6520.2010.00431.x

Masulis, R. W. (1983). The impact of capital structure change on firm value: Some estimates. The Journal of Finance, 38(1), 107-126. https://doi.org/10.1111/j.1540-6261.1983.tb03629.x

Meles, A., Porzio, C., Sampagnaro, G., \& Verdoliva, V. (2016). The impact of the intellectual capital efficiency on commercial banks performance: Evidence from the US. Journal of Multinational Financial Management, 36, 64-74. https://doi.org/10.1016/j.mulfin.2016.04.003

Millán, J. M., Congregado, E., Román, C., \& Praag M. (2014). The value of an educated population for an individual's entrepreneurship success. Journal of Business Venturing, 29(5), 612-632. https://doi.org/10.2139/ssrn.1853223

Ndofor, H. A., Sirmon, D. G., \& He, X. (2015). Utilizing the firm's resources: How TMT heterogeneity and resulting faultlines affect TMT tasks. Strategic Management Journal, 36(11), 1656-1674. 
https://doi.org/10.1002/smj.2304

Oh, I. S, Kim, S., \& Van Iddekinge, C. H. (2015). Taking it to another level: Do personality-based human capital resources matter to firm performance. Journal of Applied Psychology, 100(3), 935-947. https://doi.org/10.1037/a0039052

Podsakoff, P. M., \& Organ, D. (1986). Self-reports in organizational research: Problems and prospects. Journal of Management, 12(4), 531-544. https://doi.org/10.1177/014920638601200408

Qian, C., Cao, Q., \& Takeuchi, R. (2013). Top management team functional diversity and organizational innovation in China: The moderating effects of environment. Strategic Management Journal, 34(1), 110-120. https://doi.org/10.1002/smj.1993

Ross, S. A. (1977). The determination of financial structure: The incentive-signaling approach. The Bell Journal of Economics, 8(1), 23-40. https://doi.org/10.2307/3003485

Samagaio, A., \& Rodrigues, R. (2016). Human capital and performance in young audit firms. Journal of Business Research, 69(11), 5354-5359. https://doi.org/10.1016/j.jbusres.2016.04.137

Subramaniam, M., \& Youndt, M. A. (2005). The influence of intellectual capital on the types of innovative capabilities. Academy of Management Journal, 48(3), 450-463.

Timmons, J. A. (1979). Careful self-analysis and team assessment can aid entrepreneurship. Harvard Business Review, 57(6).

Unger, J., Rauch, A., Frese, M., \& Rosenbusch, N. (2011). Human capital and entrepreneurial success: A meta-analytical review. Journal of Business Venture, 26(3), 341-358. https://doi.org/10.1016/j.jbusvent.2009.09.004

Zahari, A. S. M. (2018). Moderating effect of innovation human capital and small firm performance in construction industry: The Malaysia case. Journal of Applied \& Fundamental Sciences, 10(1), 772-792. https://doi.org/10.4314/jfas.v10i1s.57

Zolin, R., Kuckertz, A., \& Kautonen, T. (2011). Human resource flexibility and strong ties in entrepreneurial teams. Journal of Business Research, 64, 1097-1103. https://doi.org/10.1016/j.jbusres.2010.11.026

\section{Copyrights}

Copyright for this article is retained by the author(s), with first publication rights granted to the journal.

This is an open-access article distributed under the terms and conditions of the Creative Commons Attribution license (http://creativecommons.org/licenses/by/4.0/). 